\title{
IPTEKS SISTEM INFORMASI MANAJEMEN KEUANGAN DAERAH PADA UPTD BALAI PELATIHAN KESEHATAN PROVINSI SULAWESI UTARA
}

\author{
Poppy S. Arota ${ }^{1}$, Fransisca G. Daleno ${ }^{2}$, Reklesia B. A. Rumbayan ${ }^{3}$, Virginia P. Kaligis ${ }^{4}$, \\ I Gede Suwetja ${ }^{5}$ \\ 1,2,3,4,5 Jurusan Akuntansi, Fakultas Ekonomi dan Bisnis Universitas Sam Ratulangi, Jl. Kampus Unsrat, Manado, \\ 95115, Indonesia \\ E-mail : poppyarota27@gmail.com
}

\begin{abstract}
Implementation of SIMDA at UPTD Health Training Center of North Sulawesi Province used method applied finance SIMDA2.7.0.12 accrual based at UPTD Health Training Center of North Sulawesi Province was based on the Ordinance Ministry of Home Affairs No. 132006 about financial management is started of stages of planning, administration, accounting and reporting. Application techniqueSIMDA2.7.0.12version accrual based : according to the Ordinance Ministry of Home Affairs No. 132006 IPTEKS technique who applied on manufacture of SIMDA are covers by Budgeting Planning : RKA, RAPBD and other of DPA. Administration :Letter of Provision of Funds (SPD), Letter of Request Payment (SPP). From implementation of examination result finance at UPTD Health Training Center of North Sulawesi Province is showed : implementation of SIMDA 2.7.0.12accrual based has already done through the products produced, namely budgeting and administration have no constraints, while the obstacles faced in accounting and reporting products in producing Operational Reports (LO) and Budgeting and Administration is carried out according to the Ordinance Ministry of Home Affairs No. 13 2006about financial regional management, while the accounting reporting process is carried out according to the Ordinance Ministry of Home Affairs No. 642013 about the application of accrual based government accounting standards. Keywords: Implementation, finance management, accrual based
\end{abstract}

\section{PENDAHULUAN}

Kemajuan teknologi informasi telah mengubah carapemerintah daerah pemerintah dalam melaporkan informasi keuangan. Sehingga auditor banyak akan meneumukan dimana lebih banyak data tersimpan dalam media elektronik dari pada media kertas. Sehingga pemerintah daerah menyadari perlunya laporan keuangan yang berkualitas dan sesuai dengan peundang-undangan. Sesuai amanat PP No. 71 Thn 2010 yaitu tentang SAP sebagai peraturan pengganti PP No. 24 Thn 2005, dimana PP 71 Thn 2010.dikatakan pemerintah menerapkan standar akuntansi pemerintah berbasis akrual. Dalam ini pemerintah mengharuskan pemerintah mengharuskan pemerintah daerah menggunakan basis akrual dalam pengelolaan keuangan. Keuangan daerah adalah bagian yang tidak dapat dipisahkan dari pengelolaan keuangan daerah berdasarkan materi perturan dalam negeri No. 55 Thn 2008 yaitu mengenai cara penatausahaan, penyusunanan laporan pertanggungjawaban bendahara serta pendampingnya maupun perturan mentri dalam negri No. 13 Thn 2006 tentang pengelolaan pedoman keuangan daerah dan di sempurnakan dengan perturan mentri dalam negri No. 59 Thn 2007. Penatausahaan melingkupi antara lain penyediaan dana SPD, SPP, SPP-UP (uang persediaan ), SPP-GU, SPP-LS, pencairan dana (SP2D), serta penggunaan pertanggung jawaban penggunaan dana.

Uang persediaan merupakan istilah yang muncul dalam permendagri No. 13 Thn 2006 tentang pedoman pengelolaan keuangan daerah. Menurut pasal 1 angka 66 permendagri No. 13 tahun 2006 dijelaskan bahwa uang persediaan (SPP) adalah dokumen yang bendahara 
pengeluaran ajukan untuk permintaan dengan pembayaran langsung. Sehubungan dengan hal yang sudah dijelaskan diatas, pemerintah daerah provinsi Sulawesi Utara, berupaya menerapkan sistem laporan keuangan daerah dengan bekerja sama dengan badan pengawasan keuangan dan pembangunan (BPKP) untuk mewujudkan sebuah system pelaporan keuangan yang berbasis teknologi yang terintegrasi dalam sebuah data base, oleh karena itu Balai Pelatihan Kesehatan Provinsi Sulawesi Utara juga memanfaatkan perkembangan teknologi dengan menerapkan sistem informasi Manajemen Keuangan Daerah (SIMDA) dalam pelaksanaan pengelolaan keuangan yang sesuai perturan yang berlaku transparan efektif, efisien, akuntabel dan auditabl, hal ini dilakukan agar dapat meningkatkan kualitas laporan keuangan.

\section{LANDASAN TEORI}

Standar akuntansi pemerintahan. Standar Akuntansi Pemerintah (SAP) di tetapkan dalam PP No. 71 Thn 2010 sebagai penganti perturan yang ditetapkan pemerintah Nomor 24 Thn 2005. Standar akuntansi pemerintah dibuat dalam bentuk suatu pernyataan standar akuntansi pemerintah.Standar akuntansi pemerintahan dipergunakan dalam acuan untuk menyusun suatu laporan keuangan pemerintah dalam pemerintah pusat dan pemrintah daerah.

Sistem akuntansi pemerintah daerah. Hariadi, Restianto dan Bawono (2010;131), keuangan akuntansi daerah, yaitu suatu proses indentifikas, pengkuran, pencatatan serta catatan laporan transaksi ekonomi untuk sesuatu yang dijadikan sebagai informasi dlam rangka pengambilan keputusan ekonomi dari pihak-pihak yang diperlukan.

Sistem dan prosedur akuntansi pemerintah daerah. Akuntansi sistem Pemerintah Daerah sekurang-kurangnya meliputi : (1) Akuntansi Prosedur Penerimaan Kas; (2) Akuntansi Prosedur Pengeluaran Kas; (3) Akuntansi Prosedur Aset Tetap/Barang Milik Daerah; dan (4) Akuntansi Prosedur Selain Kas. Keuangan daerah dilakukan oleh direktur pengelolaan keuangan daerah yang melaukukan pencatatan transaksi-transaksi yang dilakukan oleh para pemerintah daerah.

Pengertian informasi sistem manajemen keuangan daerah. Aplikasi komputer keuangan merupakan sebuah program yang dapat membantu pemerintah dalam mengelola keuangan daerah secara rinci. Dalam peraturan pemerintah No. 58 Thn 2005 tentang pengelolaan keuangan daerah menjelaskan bahwa semua kewajiban dan hak keuangan daerahdalam rangka penyelenggranan dapat dinilai dengan uang.

Pengelolaan Keuangan Daerah. Berdasarkan peraturan yang telah ditetapkan oleh pemerintah No. 13 Thn 2006 tentang keuangan daerah yang telah dikelola dan telah diubah menjadi perturan dalam negeri Nomor 59 Thn 2007, terakhir kalinya diubah menjadi PERMENDAGRI N0. 21 Tahun 2011 adalah seluruh kegiatan yang mencakup semua pengelolaan keuangan daerah.

Penatausahaan Pengelola Keuangan Daerah. Keuangan daerah yang dikelola melalui manajemen keuangan daerah. Manajemen keuangan daerah merupakan proses perencanaan, pengorganisasian terhadap semua hak dan kewajiban daerah untuk penyelenggaraan pengelolaan keuangan daerah.

\section{METODE DAN TEKNIK PENERAPAN IPTEKS}

\subsection{Metode Penerapan Ipteks}

Ipteks yang digunakan yaitu mengimplementasikan sistem informasi manajemen daerah (SIMDA) keuangan dengan peraturan dalam negeri No. 13 Thn 2006 pada UPTD. Balai Pelatihan Kesehatan Provinsi Sulawesi Utara, sehingga bias meningkatkan kualitas laporan keuangan. 


\subsection{Teknik Penerapan Ipteks}

Teknik yang diterapkan adalah melakukan serta turut membantu dalam proses pembuatan laporan keuangan dengan membuat Surat Penyediaan Dana(SPD), Surat Perintan Membayar (SPM), Surat Pertanggung Jawaban (SPJ), Surat Perintah Pencairan Dana (SP2D), beserta register formulir-formulir penegndalian BAPELKES Prov. Sulut berdasarkan pengalaman tersebut maka implementasi SIMDA keuangan berdasarkan PERMENDAGRI Nomor 13 Tahun 2006, Tentang Pedoman Pengelolaan Keuangan Daerah melipti (1) Penganggaran, (2) Penatausahaan, (3) Akuntansi dan Pelaporan.

\section{PEMBAHASAN}

\subsection{Gambaran Objek Penerapan Ipteks}

UPTD Balai Pelatihan Kesehatan (BAPELKES) Provinsi Sulawesi Utara berlokasi di Jalan Parigi tujuh No. 22, Malalayang Satu, dengan Sertifikat Hak Pakai No. 78 Tahun 1999,Luas Tanah 4.662 M2, dan Ijin Mendirikan Bangunan No. 434/XII/DTK/WM/2000. Dengan Visi : "Terwujudnya Sulawesi Utara yang Berdikari dalam Ekonomi, Berdaulat dalam Pemerintahan dan Politik, serta Berkepribadian dalam Budaya,melalui BAPELKES yang Berkualitas dan Berdaya Saing"dan Misi : 1). Mengembangkan Institusi Pelatihan yang Berkualitas, berbasis Teknologi Informasi, 2). Memantapkan Pembangunan Sumber Daya Manusia Kesehatan yang Berkepribadian dan Berdaya Saing melalui Pelatihan yang Terakreditasi, 3). Meningkatkan Pelayanan yang Berorientasi pada Kepuasan Pelanggan, 4). Mengembangkan Kemitraan dibidang Pelatihan.

\subsection{Pembahasan}

Produk yang dihasilkan sistem manajemen daerah UPTD Balai Pelatihan Kesehatan Provinsi Sulawesi Utara, adalah proses penganggaran, penatausahaan serta akuntansi dan pelaporan. Output yang dihasilkan adalah :

Penggangaran : (1). RKA (Rencana Kerja Anggaran), sesuai dengan peraturan dalam negeri No 13 Thn 2006 menyangkut pengelolan keuangan daerah, dimaksud dalam rencana kerja anggran (RKA). yaitu program atau kegiatan kerja perangkat derah. Dalam peraturan dalam negri No. 13 Thn 2006 tentang pengelolaan keuangan daerah yang dimaksud atas dokumen rencana kerja anggran yaitu suatu dokumen yang berisi program dan satuan kerja perangkat daerah.dalam peraturan dalam negri No. 13 Thn 2006 mencakup penyediaan keuangan daerah.

Penatausahaan : SPD (Surat Penyediaan Dana) Surat Penyediaan Dana (SPD), dalam peraturan dalam negri No. 13 Thn 2006 mencakup keuangan daerah. Yang dimaksud dalam surat penyediaan dana (SPD) merupakan dokumen untuk melaksanakan dana kegiatan dasar untuk penerbitan pembayaran.

Proses Penatausahaan dalam Implementasi Sistem Informasi Manajemen pada UPTD Balai Pelatihan Kesehatan Manado menghasilkan produk penatausahaan sebagai berikut: Surat Permintaan Pembayaran (SPP), dalam peraturan dalam negri No. 13 Thn 2006 mencakup penyediaan keuangan daerah. Yang dimaksud dalam surat permintaan pembayaran merupakan suatu dokumen yang digunakan oleh pengguna yang bertanggungjawab atas pelaksanaan kegiatan. Berdasarkan hasil observasi dan telaah dokumen diperoleh informasi terkait prosedur pengujian Surat Perintah Membayar (SPM), dilaksanakan Pejabat Pembuat Komitmen (PPK) tiap SKPD di lingkungan Balai Pelatihan Kesehatan.Dalam melengkapi dokumen SPP-UP/GU/TU/LS yang telah dilampirkan dan telah disesuaikan dengan DPASKPD yang terkait. Perancangan SPM dibuat dalam dua rangkap sementara dokumen aslinya dikirim kepada kuasa BUD yang telah dilengkapi dengan dokumen. SPM harus ditandarangani kepda SKPD dan stempel SKPD serta ditandatangni direktur perusahaan dan stempel perusahaan (khusus untuk tagihan pihak ketiga). Secara umum pelaksanaan pengajuan Surat Perintah Pencairan Dana (SP2D) pada UPTD Balai Pelatihan Kesehatan 
Manado sudah berjalan dengan baik.Akuntansi dan Pelaporan, dalam Implementasi Sistem Informasi Manajemen Daerah pada UPTD Balai Pelatihan Kesehatan Manado menghasilkan produk Akuntansi dan Pelaporan yaitu LRA.

\section{KESIMPULAN DAN SARAN}

\subsection{Kesimpulan}

Terkait dengan Produk yang dihasilkan Sistem Informasi Manajemen Daerah (SIMDA) Keuangan Versi 2.7.0.12 Berbasis Akrual , disimpulkan bahwa produk yang dihasilkan penganggaran dan penatausahaan sudah tidak memiliki kendala dan aplikasi ini sangat memudahkan dan membantu UPTD Balai Pelatihan Kesehatan Manado dalam pengelolaan keuangannya, namun produk Akuntansi dan Pelaporan memiliki kendala dalam menghasilkan Laporan Operasional (LO) Pembiayaan dikarenakan Peraturan yang digunakan pelaksanaan proses penganggaran dan penatausahaan pada UPTD Balai Pelatihan Kesehatan Manado dilaksanakan berdasarkan Peraturan Menteri Dalam Negeri Nomor 13 Tahun 2006 tentang Pedoman Pengelolaan Keuangan daerah, sedangkan proses akuntansi dan pelaporan dilaksanakan berdasarkan Peraturan Menteri Dalam Negeri Nomor 64 Tahun 2013 tentang Penerapan Standar Akuntansi Pemerintahan Berbasis Akrual.

\subsection{Saran}

Untuk lebih meningkatkan fungsi dari aplikasi SIMDA agar supaya dalam pelaksanaannya lebih mudah dan lebih cepat dalam beroperasional kegiatan dan Pengelolaan aplikasi SIMDA sangat membantu dalam menunjang kegiatan operasional kantor untuk itu aplikasi SIMDA harus lebih diperbaharui lebih bagus.

\section{DAFTAR PUSTAKA}

(n.d.). http://retrieved from.bpkp.go.id/konten/333/versi-2.1.bpkp (2014,09). Rentrieved from http://herisulistiyonomts 142730639.blogspot.com/2014/09/?m=1

Balai Pelatihan Kesehatan Provinsi Sulut (n.d). Peraturan Undang-Undang No. 78 Tahun 1999 Tentang Kedudukan, Susunan Organisasi, Serta Tugas dan Fungsi UPTD. Balai Pelatihan Kesehatan Provinsi Sulawesi Utara.

Elim, D. D.(2015). Evaluasi sistem informasi penerapan manajemen daerag DPPKA kabupaten kepulauan sangihe.

Nikita, (2016). Proseedur dan system belanja akuntansi langsung pada pelayanan kantor perijinan Prov. Sulut. Vol 16 No 04, 1143

Novlentina Pasi, A. K. (2017). System informasi implementasi manajemen daerah keuangan berbasis akrual pada kabupaten pemerintah dairi. Vol 7 No. 1

Onibala, M (2014). Prosedur dan sistem evaluasi akuntansi pengeluaran kasbelanja langsung pada dinas pekerjaan umum

Peraturan dalam negeri No. 13 Thn 2006-Tentang pengelolaan pedoman keuangan daerah. (n.d).

Peraturan dalam negeri No. 55 Thn 2008 Tentang tata cara penganggran, penatausahaan, dan penyusunan laporan laporan pertanggungjawaban bendahara serta penyampainnya. (n.d).

Pilat, J. J. (n.d). penerapan analisis sistem informasi manajemen daerah (SIMDA) keuangan untuk pengelolaan keuangan daerah.

Rahmatia, D. R (2016). Penatausahaan analisis penyusunan laporan keuangan pertanggungjawaban serta peyampaian pada dinas pendapatan keuangan daerah bone bolango. Jurnal EMBA, Vol 4 No. 1, 746 